\title{
PENGEMBANGAN MASYARAKAT SETIAWARGI BERBASIS POTENSI DAERAH \\ ${ }^{1}$ Yus Darusman, ${ }^{2}$ Mumu, ${ }^{3}$ Ahmad Hamdan \\ 1,2,3 Jurusan Pendidikan Masyarakat Fakultas Keguruan dan Ilmu Pendidikan Universitas Siliwangi yusdarusman@unsil.ac.id
}

\begin{abstract}
ABSTRAK
Pelaksanaan pengabdian pada masyarakat dengan skim Iptek bina bagi Masyarakat (IbBM) yaitu untuk meningkatkan pengetahuan masyarakat Setiawargi tentang pentingnya pendidikan dan juga masyarakat dapat melihat potensi yang dimiliki, baik itu potensi alam dan sumber daya manusia agar dapat dimanfaatkan dengan baik sehingga dapat meningkatkan kemandirian serta ekonomi masyarakat. Permasalahan yang ditemui di kelurahan Setiawargi diantaranya yaitu masih rendahnya tingkat pendidikan dan kesadaran akan pentingnya pendidikan, banyaknya potensi alam yang belum dimanfatkan dengan baik, seperti banyak nya pohon singkong yang tidak di olah sehingga belum menghasilkan nilai tambah terutama nilai tambah dalam segi ekonomi. Pelaksanaan pengabdian kepada masyarakat ini bekerja sama dengan Forum Komunikasi PKBM Kota Tasikmalaya dan Kelurahan Setiawargi. Adapun pelaksana kegiatan Pengabdian kepada masyarakat dilakukan oleh dosen jurusan Pendidikan Masyarakat sebanyak 2 orang yang dibiayai oleh LP2M-PMP Universitas Siliwangi.

Kata kunci: pemberdayaan, potensi daerah, pengembangan masyarakat
\end{abstract}

\begin{abstract}
Implementation of community service with Iptek Bina bagi Masyarakat (IbBM) scheme, namely to increase the knowledge of the Setiawargi community about the importance of education and also the community can see the potential they have, both natural and human potential so that they can be utilized properly so as to increase independence and the economy Public. Problems encountered in Setiawargi village include the low level of education and awareness of the importance of education, the many natural potentials that have not been properly utilized, such as many cassava trees that are not processed so that they do not produce added value, especially added value in economic terms. The community service was carried out in collaboration with the Tasikmalaya City PKBM Communication Forum and Setiawargi Village. The implementers of community service activities are carried out by 2 people lecturers majoring in Community Education funded by LP2M-PMP Siliwangi University. Keywords: empowerment, regional potential, community development
\end{abstract}




\section{PENDAHULUAN}

Sumber daya manusia merupakan modal penting guna mewujudkan tujuan dan cita-cita bangsa. Oleh karena itu upaya pengembangan sumber daya manusia menjadi kebutuhan yang utama dan sangat penting seiring dengan berbagai perubahan, tuntutan serta kemajuan yang terjadi di masyarakat yang berlangsung begitu cepat.

Kompleksitas perkembangan zaman dan globalisasi menuntut setiap individu untuk memahami ilmu pengetahuan, teknologi dan informasi serta pengembangan potensi baik itu potensi manusia ataupun potensi daerah yang bisa terus dikembangkan. Pengembangan diarahkan pada upaya menghasilkan sumber daya manusia yang berdaya guna dan fungsional sesuai kebutuhan untuk bisa memanfaatkan potensi daerahnya.

Persoalan kemiskinan merupakan permasalahan yang seakan-akan tidak ada habisnya di negeri ini. Sejak sebelum Indonesia merdeka sampai pada saat Indonesia sudah merdeka, bahkan sampai pada saat era globalisasi permsalahan kemiskinan masih menghantui masyarakat. Pemerintah dengan segala upaya dan kebijakannya dalam mengurangi permasalahan kemiskinan di masyarakat, akan tetapi masih belum ada perubahan yang signifikan.

Masyarakat yang selama ini hidup dalam ketertinggalan belum mampu mengikuti pola pemberdayaan terpadu, hal ini dikarenakan berbagai permasalahan yang terjadi, diantaranya yaitu: masih belum optimalnya peran pemerintah kota/kabupaten dalam memberdayakan masyarakat khususnya dalam pengembangan sumber daya manusia, masyarakat masih terbelenggu oleh permasalahan-permasalahan yang berkaitan dengan kebutuhan primer atau ekonomi, dan model pembangunan yang sentralistik menjadikan masyarakat menjadi kurang kreatif dan bergantung pada pemerintah.

Menurut Syawie dalam Nainggolan (2012, hlm. 1) kemiskinan merupakan kondisi saat seseorang atau sekelompok orang tak mampu memenuhi hak-hak dasarnya untuk mempertahankan dan mengembangkan kehidupan yang bermartabat. Kemiskinan merupakan persoalan yang sangat kompleks dan kronis, sehingga penanggulangannya diperlukan solusi yang terintegrasi dari berbagai komponen yang sifatnya berkelanjutan.

Selama ini proses pembangunan masyarakat telah banyak merubah kondisi kehidupan masyarakat. Pada sebagian masyarakat pembangunan telah menjadikan masyarakat pada kehidupan yang lebih baik, akan tetapi masih ada juga masyarakat belum berkembang bahkan masih miskin dan terbelakang. Oleh karena itu pelaksanaan pembangunan bersifat dinamis, yang disesuaikan dengan permasalahan-permasalahan baru yang muncul.

Pengembangan masyarakat merupakan gerakan yang dirancang guna meningkatkan taraf hidup keseluruhan masyarakat melalui partisipasi aktif dan inisiatif dari masyarakat. Seperti yang diungkapkan oleh Howard Kingsley dalam Sudjana (2004; 4) bahwa pada dasarnya bentuk dari hasil belajar dapat di bagi menjadi tiga macam, yaitu 1) keterampilan dan kebiasaan; 2) pengetahuan dan pengertian; 3) sikap dan cita-cita. 
Pendidikan luar sekolah, memiliki kajian diantaranya adalah pemberdayaan masyarakat. Pemberdayaan masyarakat memiliki peran yang sangat sentral bagi masyarakat untuk menjadi lebih berdaya, baik itu dalam hal pendidikan, ekonomi, kesehatan dan lainnya. Untuk menciptakan masyarakat yang sadar akan pentingnya pendidikan, dan pemberdayaan terkadang tidak selalu muncul secara langsung dari masyarakat, akan tetapi dibutuhkan orang lain yang datang dari luar wilayah tersebut untuk memberikan pencerahan terhadap hal-hal yang bisa meningkatkan tingkat keberdayaan masyarakat.

Proses pengembangan dan pembangunan masyarakat harus dirancang dan disiapkan untuk memenuhi kebutuhan masyarakat. Program-program yang akan dilakukan diawali dengan adanya analisis kebutuhan masyarakat, hal ini dilakukan untuk mendapatkan data awal apa saja yang memang dirasa dibutuhkan oleh masyarakat. Dalam melakukan analisis kebutuhan haru sesuai dengan apa yang dirasakan oleh masyarakat (felt need), bukan berdasarkan apa yang diinginkan oleh masyarakat (lists of wants) yang bersifat sesaat. Menggali kebutuhan masyarakat harus dilakukan secara cermat agar program yang dilakukan bersifat bottom up yaitu berasal dari bawah yaitu masyarakat yang merasakan kebutuhannya, bukan dari kebutuhan atau keinginan beberapa orang saja. Proses pengembangan masyarakat (community development) memiliki tujuan untuk meningkatkan partisipasi masayarakat dan rasa memiliki (participating and belonging togheter) terhadap program yang dilaksanakan untuk meningkatkan kemandirian masyarakat sebagai unsur pemberdayaan masyarakat (Zamhariri, 2008).

Permasalahan yang terjadi di Setiawargi memang sangat kompleks, diantaranya yaitu kekurangan air bersih jika masuk pada musim kemarau, tingkatkan pendidikan yang masih rendah, kemiskinan, potensi daerah yang belum dioptimalkan dan permsalahan social lainnya. Upaya yang dilakukan yaitu melalui pengembangan potensi daerah berupa pengolahan hasil pertanian dan juga pengembangan pariwisata yang berbasis masyarakat. Dalam pengabdian ini kami sebagai tim Jurusan Pendidikan Masyarakat berusaha menjembatani permasalahan yang ada pada kondisi saat ini dilapangan.

Dengan adanya program pengembangan masyarakat ini diharapkan masyarakat dapat berkembang menjadi masyarakat pembelajar (learning society) dan dapat mengembangkan potensi daerah agar lebih berdaya dan bersaing dengan masyarakat lainnya serta dapat meningkatkan IPM masyarakat Setiawargi.

\section{METODOLOGI}

Berjalannya pelaksanaan kegiatan pengabdian kepada masyarakat melibatkan 2 lembaga mitra, yaitu Forum Komunikasi PKBM Kota Tasikmalaya dan Kelurahan Setiawargi. Kerjasama yang dilakukan dengan mitra Pemerintah Kelurahan Setiawargi yaitu dalam rangka melaksanakan program pengembangan masyarakat berbasis potensi daerah agar masyarakat dapat mengembangan dirinya serta menjadi masyarkat yang gemar belajar (learning society) serta dapat memanfaatkan potensi yang ada didaerahnya dengan baik. Pada pelaksanaannya kegiatan dibantu oleh perwakilan dari Forum Komunikasi PKBM Kota Tasikmalaya untuk 
meningkatkan kemampuan serta diharapkan dapat meningkatkan ekonomi masyarakat sesuai dengan potensi daerah tersebut.

Sasaran dari pengabdian ini adalah para masyarakat usia produktif kelurahan Setiawargi, dengan harapan mereka dapat memahami arti pentingnya pendidikan serta memahami potensi yang ada didaerahnya untuk dapat dimanfaatkan dengan baik. Permasalahan yang dijadikan prioritas mitra yang disepakati bersama diantaranya:

1. Kondisi ekonomi masyarakat yang miskin

2. Tingkat pendidikan yang rendah

3. Tingginya tingkat pengangguran

4. Potensi sumber daya alam yang belum dimanfaatkan dengan baik

5. Potensi daerah yang belum dioptimalkan

\section{A. Tahap Persiapan}

Sebelum melakukan pengabdian pada masyarakat melalui pengembangan masyarakat Setiawargi Berbasis Potensi daerah dimulai dengan melakukan observasi awal terhadap para masyarakat untuk mengetahui permasalahan yang terjadi. Berdasarkan data BPS Kota Tasikmalaya Tahun 2018 kelurahan setiawargi merupakan kelurahan dengan tingkat IPM yang paling rendah di Kota Tasikmalaya.

Peneliti juga melakukan kordinasi dengan ketua Forum Komunikasi PKBM Kota Tasikmalaya untuk melakukan program yang sesuai dengan harapan masyarakat dan sesuai dengan permasalahan yang terjadi agar dibantu penyelesaian permasalahan yang dihadapinya tersebut.

B. Tahap Pelaksanaan

Dalam upaya pelaksanaan pengembangan masyarakat setiawargi berbasis potensi daerah di kelurahan setiawargi dilaksanakan melalui beberapa tahap:

1. Sosialisasi

Sosialisasi program dilaksanakan setelah tahap persiapan selesai yaitu dengan melakukan pertemuan dengan masyarakat yang akan mengikuti pengembangan masyarakat tentang program yang akan dilaksanakan.

2. Penyampaian Materi

Peserta diberikan materi seputar pentingnya pendidikan, kepemudaan, pengembangan potensi daerah, pengembangan wisata daerah, dan pelatihan pengeolahan produk unggulan setiawargi.

3. Evaluasi

Evaluasi dilakukan kepada peserta pelatihan setelah semua tahap terlaksana yaitu dengan penyebaran kuesioner pada peserta pelatihan tentang program yang dilaksanakna oleh tim pengabdian pada masyarakat.

4. Penyusunan Laporan

Penyusunan laporan merupakan tahap akkhir pelaksanaan program yaitu dengan menyusun dan membuat laporan hasil kegiatan secara keseluruhan. 


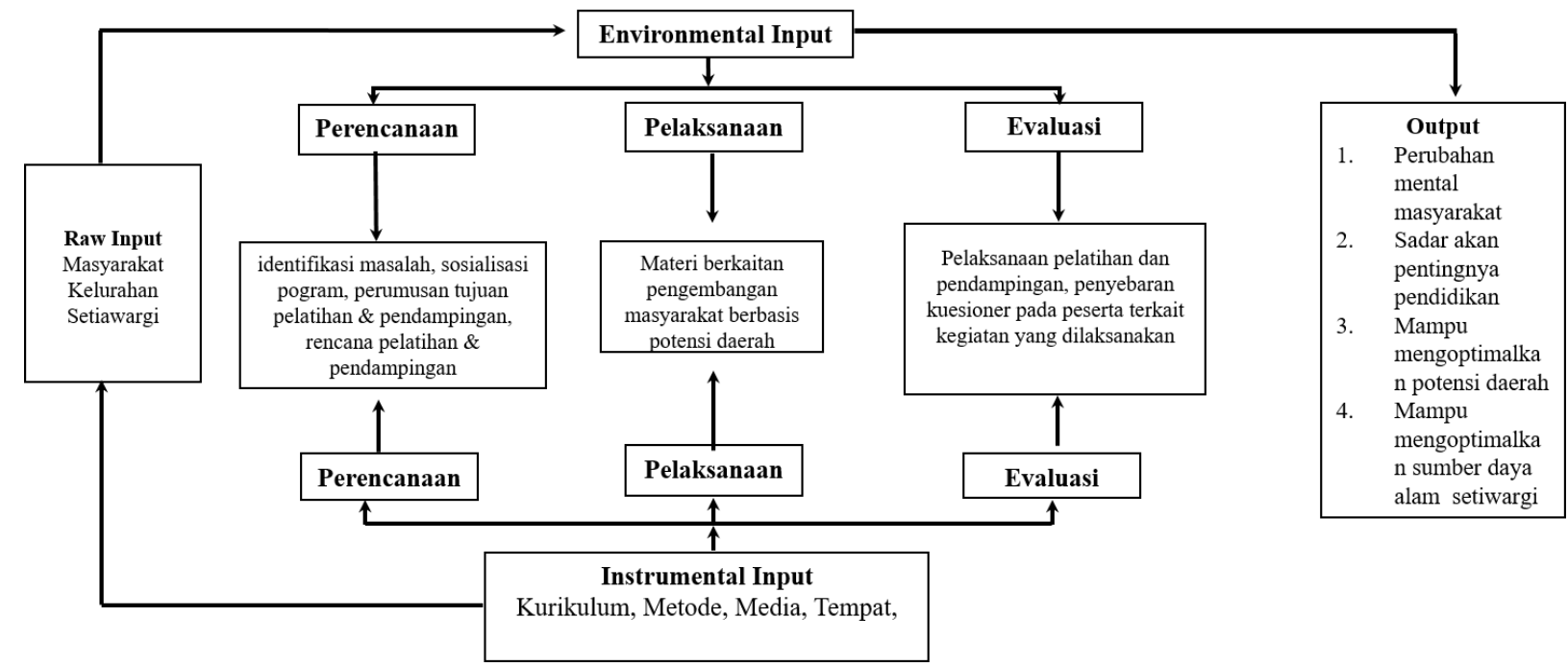

Gambar 2.1

Desain Pengabdian Kepada Masyarakat Pengembangan Masyarakat Setiawargi

Berbasis Potensi Daerah

\section{HASIL DAN PEMBAHASAN}

Pengembangan Masyarakat Setiawargi Berbasis Potensi Daerah ini dilaksanakan pada tanggal 5 Agustus 2019. Pelaksanaan kegiatan Pengabdian kepada masyarakat dilakukan dengan kegiatan seminar yang bertujuan membuka wawasan para masyarakat Kelurahan Setiawargi dan pelatihan pengolahan makanan dari bahan baku singkong agar memiliki nilai jual yang lebih.

Pada pelaksanaannya kegiatan dikemas dalam bentuk sharing atau overview tentang potensipotensi daerah di Setiawargi yang dapat dimanfaatkan dan memiliki nilai jual yang lebih serta menguatkan para peserta untuk sadar akan pentingnya pendidikan. Pada penguatan ekonomi, peserta diberi pelatihan pengolahan makanan dari bahan baku singkong berupa donut, sate donut dengan toping coklat, dan jajanan pasar lainnya.

Materi disampaikan oleh dosen pelaksana pengabdian kepada masyarakat, para mitra yaitu pemerintah kelurahan setiawargi dan FK PKBM Kota Tasikmalaya dan juga mahasiswa kelas karyawan jurusan pendidikan masyarakat universitas siliwangi yang menjadi tim kegiatan pengabdian kepada masyarakat. Berikut ini adalah materi kegiatan pengabdian kepada masyarakat yang disampaikan:

Table 3.1

Materi Kegiatan

\begin{tabular}{|l|l|l|l|}
\hline Waktu & \multicolumn{1}{|c|}{ Kegiatan } & Pengisi/Narasumber & \multicolumn{1}{c|}{ Metode } \\
\hline $3 \times 30$ & 1. Wawasan & - Prof. Dr. Yus & 1. Ceramah \\
menit & Pentingnya & Darusman, M.Si. & 2. Diskusi \\
& Pendidikan & - Drs. H. Mumu, & $\begin{array}{c}\text { 3. Problem } \\
\text { solving }\end{array}$ \\
& & M.Pd. & \\
& & - Pemerintah & \\
\hline
\end{tabular}




\begin{tabular}{|c|c|c|c|}
\hline & potensi daerah & $\begin{array}{l}\text { Kelurahan } \\
\text { Setiawargi } \\
\text { - } \text { FK PKBM Kota } \\
\text { Tasikmalaya }\end{array}$ & \\
\hline $\begin{array}{l}4 \times 30 \\
\text { menit }\end{array}$ & $\begin{array}{l}\text { 1. Praktek Pengolahan } \\
\text { singkong }\end{array}$ & $\begin{array}{l}\text { - } \text { Mahasiswa Kelas } \\
\text { karyawan penmas } \\
\text { UNSIL } \\
\end{array}$ & 1. Praktek \\
\hline
\end{tabular}

\section{KESIMPULAN DAN SARAN}

Program Pengabdian Kepada Masyarakat dengan skim Ipteks bagi Bina Masyarakat (IbBM) sudah dilaksanakan berupa pemberian materi tentang pentingnya pendidikan dan pengembangan potensi daerah serta pelatihan keterampilan membuat olahan makanan berbahan singkong yang memiliki nilai jual tambahan. Dari hasil kegiatan tersebut masyarakat mendapatkan pengetahuan baru tentang pengembangan potensi daerah dan keterampilan pengolahan makanan berupa donat singkong, getuk singkong mawar, sate donut dengan toping coklat.

Berjalannya kegiatan ini diharapkan tidak berakhir pada kegiatan pengabdian, akan tetapi dapat berdampak bagi masyarakat yang menjadi sasaran kegiatan pengabdian agar dapat terus peduli akan pendidikan keluarga nya dan meningkatkan ekonomi keluarga dari keterampilan yang sudah disampaikan oleh pemateri.

\section{DAFTAR PUSTAKA}

Nainggolan, T. (2012). Program keluarga Harapan di Indonesia: Dampak Pada Rumah Tangga Sangat Miskin di Tujuh Provinsi. Jakarta: P3KS Press.

Sudjana, D. (2004). Wawasan Sejarah Perkembangan Falsafah dan Teori Pendukung Asas. Bandung : Falah Production.

Zamhariri, 2008, Pengembangan Masyarakat: Perspektif Pemberdayaan dan Pembangunan, Volume 4, Nomor 1, Juni. 